\title{
Assessment of Serum Level of Interferon Gamma in Patients of Lupus Nephritis and without Nephritis
}

\author{
Medhat Shalaby, ${ }^{1}$ MSc, Medhat Shalaby, ${ }^{1}$ MD, Mostafa Eldahan, ${ }^{1}$ MD, Ahmed Abdelaziz, ${ }^{1}$ MD, Ibrahim \\ Metwaly, ${ }^{2}$ MD.
}

*Corresponding Author:
Abdelwahab Nasrat Bayoumy
abdelwahabnasrat@gmail.com

Received for publication January 22, 2021; Accepted February 16, 2021; Published online February 16, 2021.

Copyright 2021 The Authors published by Al-Azhar University, Faculty of Medicine, Cairo, Egypt. All rights reserved. This an open-access article distributed under the legal terms, where it is permissible to download and share the work provided it is properly cited. The work cannot be changed in any way or used commercially.

doi: 10.21608/aimj.2021.56633.1395.

${ }^{1}$ Rheumatology, physical medicine and Rehabilitation Department, Faculty of Medicine, Al-Azhar University.

${ }^{2}$ Clinical pathology Department, Faculty of Medicine, Al-Azhar University.

\begin{abstract}
Background: One of the major immunological problems is SLE (systemic lupus erythematosus), and INF (interferon) plays an important role in disease pathogenesis

Aim of the study: is to assess the level of INF gamma in sufferers with lupus nephritis in comparison to patients with non-nephritis lupus and their correlation to the disease activity.

Patients and Methods: This research was conducted on 60 persons divided into two groups: group I (group SLE) comprising 40 patients, 20 patients with nephritis and 20 patients without nephritis, and group II (control group) comprising 20 age-matched normal control persons. Disease activity assessed in patients' SLEDAI (SLE Disease Activity Index) and sera and controls were tested for the INF gamma level measured in the Human INF GAMMA ELISA (Enzyme-Linked Immunosorbent Assay) kits.

Results: In the SLE group, serum levels of INF gamma were substantially higher than in the control group and also higher in patients with nephritis than in non-nephritis group and had direct correlation with SLEDAI score, level of anti-ds DNA(anti double stranded DNA) and proteinuria.

Conclusion: For SLE patients, INF gamma may be used as a biomarker, and in renal activity is higher.
\end{abstract}

Keywords: Systemic lupus erythematosus; lupus nephritis; interferongamma

Disclosure: The authors have no financial interest to declare in relation to the content of this article. The Article Processing Charge was paid for by the authors.

Authorship: All authors have a substantial contribution to the article.

\section{INTRODUCTION}

Systemic Lupus Erythematosus (SLE) has been an inflammatory condition related to chronic immune activation and tissue damage induced by the deposition and penetration of immune complexes into susceptible organs of activated T cells. ${ }^{1}$

A widespread and extreme SLE manifestation is lupus nephritis (LN). LN is glomerulonephritis in all kidney compartments, distinguished by the accumulation of immune complexes in glomeruli and sometimes an inflammatory reaction. ${ }^{2}$

Interferon-gamma (INF- $\gamma$ ) is produced by both innate and acquired immune cells, particularly $\mathrm{T}$ cells and natural killer (NK) cells. IFN- $\gamma$ can enhance the polarization of Th1 by increasing the expression of class I and II molecules of MHC; encouraging specific cytotoxicity, and increase antigen processing and immunoglobulin switching. ${ }^{3}$
The aim of this work to assess the level of INF gamma in lupus nephritis patients relative to nonnephritis lupus patients and their correlation to the disease activity.

\section{PATIENTS AND METHODS}

The research was conducted by IN SAYED GALAL and ELHUSSIEN University hospitals on sixty individuals split into two groups:

Group I (SLE group) comprised 40 sub-grouped SLE patients in two groups: Group A: 20 patients with lupus nephritis

Group B: 20 patients with non-nephritis lupus patients. Group II (Control group) comprised 20 healthy controls age gender matched their healthy status confirmed by clinical examination and investigation. Inclusion criteria: Patients with 
systemic lupus erythematosus diagnosed with SLE classification criteria as per the American College of Rheumatology (ACR) Exclusion criteria: patients with kidney diseases, patients with history of malignancy, patients with liver diseases, and patients with diabetes.

All patients underwent the following: Informed written consent about the study. Clinical assessment: in form of: Taking of full medical history, complete clinical exam and SLEDAI score measured for all patients.

\section{Laboratory assessment:}

The sera of all patients were collected to measure blood sugar, complete blood picture, ESR, c-reactive protein, kidney function and liver function, ANA, anti DNA, C3, C4 and Serum level of INF GAMMA was measured by Human INF GAMMA ELISA (Enzyme-Linked Immunosorbent Assay) kits will be used.

The serum of the patients collected by the use of a serum separator tube (SST) and allows specimens to coagulate at roughly $1000 \times \mathrm{g}$ for 30 mins before centrifugation for $15 \mathrm{~min}$.

Immediately remove or aliquot the serum and evaluate and store specimens at $-20^{\circ} \mathrm{C}$ or $-80^{\circ} \mathrm{C}$. The microtiter plate given in this kit was pre-coated with an IFN-gamma specific antibody. Standards or specimens are then applied to the required micro-titer plate wells with IFN-gamma specific biotinconjugated polyclonal antibody preparation and Horseradish Peroxidase (HRP) conjugated Avidin is applied to each well of the microplate and incubated. Then a solution of TMB substrate is added to each well. There will be a color shift only for those wells containing IFN-gamma, biotin-conjugated antibody and enzyme-conjugated Avidin. By adding a sulphuric acid solution, the enzyme-substrate reaction is terminated, and the change in color was measured spectrophotometrically at a wavelength of $450 \mathrm{~nm} \pm 2 \mathrm{~nm}$

\section{Statistical analysis:}

The statistical package for social science version 20.0 was used to analyze reported data (SPSS Inc., Chicago, Illinois, USA). The mean \pm standard deviation of quantitative data was represented as (SD). The frequency and percentage were represented as qualitative data,

\section{RESULTS}

The patient's age in nephritis group was $39.80 \pm 11.28$ years and in non-nephritis group33.70 \pm 9.81 with female to male ratio 44:6 as shown in (Table 1 ).

The patients with nephritis classified as class III 9 (45\%), IV 6 (30\%) and IV 5 (25\%) of biopsy class as shown in figure (1).

serum level of interferon gamma was $258.50 \pm 38.15$ in SLE with nephritis and151.50 \pm 35.73 in nonnephritis group and57.70 \pm 18.15 in control group which reflects highly statistically substantial increase for group I: Nephritis and group II: without nephritis compared to control group according to their interferon gamma as shown in (Table2) and (Figure 1).

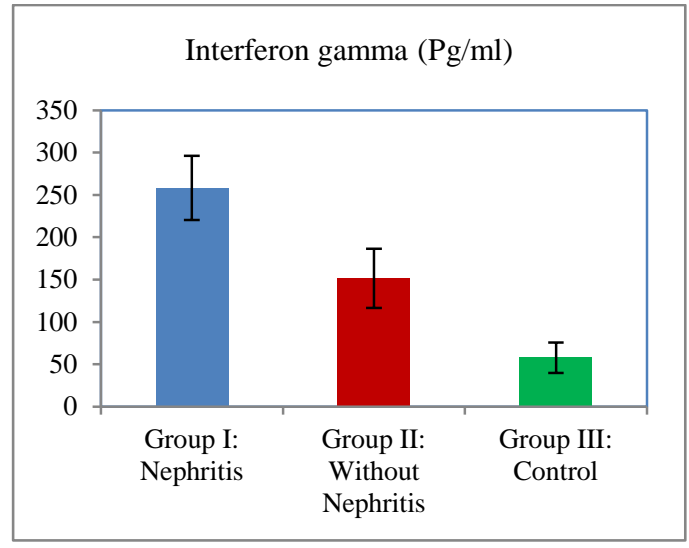

Fig 1: Bar chart according to the interferon gamma $(\mathrm{pg} / \mathrm{ml}) \quad$ among groups.

\begin{tabular}{|l|c|c|l|l|}
\hline Demographic data & $\begin{array}{c}\text { Group I: } \\
\text { Nephritis (n=20) }\end{array}$ & $\begin{array}{c}\text { Group II: Without } \\
\text { Nephritis (n=20) }\end{array}$ & Test & p-value \\
\hline $\begin{array}{l}\text { Sex } \\
\text { Female }\end{array}$ & $\begin{array}{c}16(80.0 \%) \\
4(20.0 \%)\end{array}$ & $\begin{array}{c}18(90.0 \%) \\
2(10.0 \%)\end{array}$ & $\mathrm{x} 2=0.784$ & 0.376 \\
\hline Age (years) & $39.80 \pm 11.28$ & $33.70 \pm 9.81$ & $\mathrm{t}=1.824$ & 0.076 \\
$\begin{array}{l}\text { Mean } \pm \text { SD } \\
\text { Range }\end{array}$ & $21-58$ & $18-58$ & & \\
\hline Marital Status & $16(80.0 \%)$ & $12(60.0 \%)$ & $\mathrm{x} 2=1.905$ & 0.168 \\
Married & $4(20.0 \%)$ & $8(40.0 \%)$ & & \\
Single & $2(10.0 \%)$ & $0(0.0 \%)$ & $\mathrm{x} 2=2.105$ & 0.147 \\
\hline $\begin{array}{l}\text { Onset } \\
\text { Acute } \\
\text { Gradual }\end{array}$ & $18(90.0 \%)$ & $20(100.0 \%)$ & \\
\hline
\end{tabular}

Table 1: Comparison among group I: nephritis and group II: without nephritis based on demographic data. 


\begin{tabular}{|l|c|l|c|c|l|}
\hline $\begin{array}{l}\text { Interferon } \\
\text { gamma (Pg/ml) }\end{array}$ & $\begin{array}{l}\text { Group I: } \\
\text { Nephritis (n=20) }\end{array}$ & $\begin{array}{l}\text { Group II: } \\
\text { Without } \\
\text { Nephritis (n=20) }\end{array}$ & $\begin{array}{l}\text { Group III: } \\
\text { Control (n=20) }\end{array}$ & F-test & p-value \\
\hline Mean \pm SD & $258.50 \pm 38.15$ & $151.50 \pm 35.73$ & $57.70 \pm 18.15$ & 83.811 & $<0.001^{* *}$ \\
\hline Range & $190-320$ & $100-220$ & $28-94$ & \\
\hline
\end{tabular}

Table 2: Comparison between groups according to their interferon gamma (pg/ml).

There was a high statistically substantial positive association among interferon and SLEDAI score in nephritis group, while without nephritis group significant only positive correlation as shown in table(3).

And as regard the parameters of activity in the nephritis group there was a positive correlation between levels of anti ds-DNA and the level of interferon gamma and negative correlation to the level of c3,c4 and there is no correlation with CRP. As shown in table (4).while in non nehritis group there was no correlation to the parameters of activity.

also in the nephrits group the distribution of renal biopsy was shown in figure (2) and there was no correlation between the class of renal biopsy and the level of interferon gamma while there was statistically significant positive correlation between interferon with $24 \mathrm{H}$ urinary protein as shown in table (5)and figure (3)

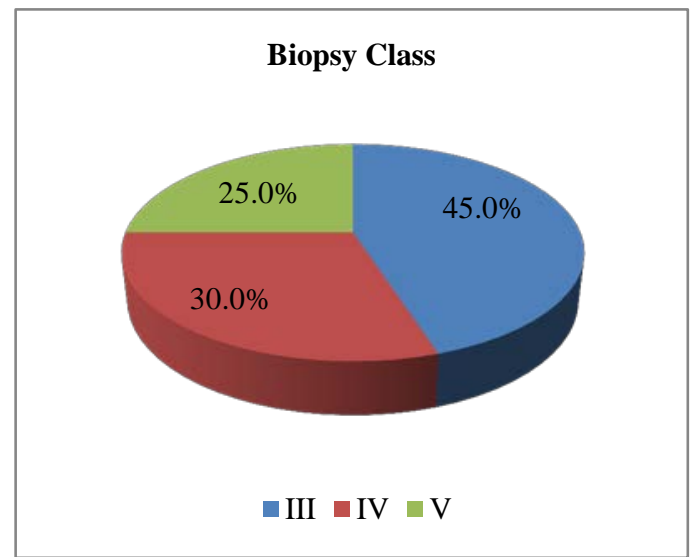

Fig 2: Pie chart showing distribution of renal biopsy among patients with nephritis.

\begin{tabular}{|l|l|l|l|}
\hline \multicolumn{2}{|c|}{} & \multicolumn{2}{l|}{ Interferon gamma (Pg/ml) } \\
\cline { 3 - 4 } \multicolumn{2}{|c|}{} & $\begin{array}{l}\text { Group I: } \\
\text { Nephritis }\end{array}$ & $\begin{array}{l}\text { Group II: } \\
\text { Without Nephritis }\end{array}$ \\
\hline $\begin{array}{l}\text { SLEDAI } \\
\text { score }\end{array}$ & r-value & 0.897 & 0.605 \\
\cline { 2 - 4 } & p-value & $<0.001^{* *}$ & $0.005^{*}$ \\
\hline
\end{tabular}

Table 3: Correlation between interferon gamma $(\mathrm{pg} / \mathrm{ml})$ with SLEDAI score, using Pearson Correlation Coefficient in each Group.

\begin{tabular}{|l|l|l|}
\hline \multirow{2}{*}{ Parameters of activity } & \multicolumn{2}{|l|}{ Interferon gamma (Pg/ml) } \\
\cline { 2 - 3 } & r-value & p-value \\
\hline Anti-Ds-DNA & 0.471 & $0.017^{*}$ \\
\hline C3 & -0.391 & $0.014^{*}$ \\
\hline C4 & -0.382 & $0.028^{*}$ \\
\hline CRP & -0.049 & 0.839 \\
\hline
\end{tabular}

Table 4: Correlation between interferon gamma $(\mathrm{pg} / \mathrm{ml})$ with parameters of activity, using Pearson Correlation Coefficient in Group I: Nephritis.

\begin{tabular}{|l|l|l|}
\hline \multirow{2}{*}{ Parameters } & \multicolumn{2}{|l|}{ Interferon gamma $(\mathbf{P g} / \mathbf{m l})$} \\
\cline { 2 - 3 } & r-value & p-value \\
\hline 24H urinary protein & 0.359 & $0.027^{*}$ \\
\hline Biopsy Class & -0.093 & 0.698 \\
\hline
\end{tabular}

Table 5: Correlation between interferon gamma $(\mathrm{pg} / \mathrm{ml})$ with $24 \mathrm{hrs}$ urinary protein and biopsy class, using Pearson Correlation Coefficient in Group I: Nephritis

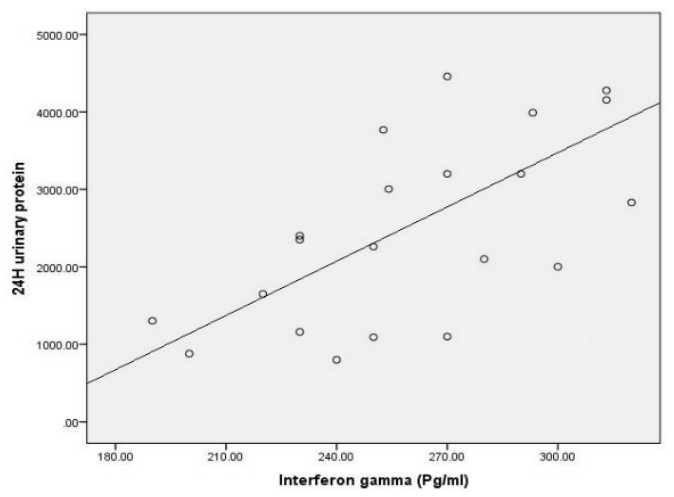

Fig 3: Scatter plot between interferon gamma $(\mathrm{pg} / \mathrm{ml})$ and 24h urinary protein Group I: Nephritis.

\section{DISCUSSION}

In our present study, we assess the level of INF- $\gamma$ in systemic lupus patient with nephritis and without nephritis and its relation to the activity of the disease in both groups by measuring its level in the sera of the peripheral blood of our patients using interferon gamma ELIZA kits and correlate that level to various elements of activity in both groups and we demonstrate the following:

There has been a substantial rise in the level of INF$\gamma$ between the systemic lupus group of patients and the age matched normal control, which is in agreement with some previous reports. ${ }^{3,4,5,6}$ 
Previous laboratory studies have shown that IFN- $\gamma$ is capable of worsening SLE disease, while anti-IFN- $\gamma$ antibodies and soluble recombinant IFN- $\gamma \mathrm{R}$ (sIFNR) are capable of delaying disease onset. ${ }^{7,8,9}$

Therefore, IFN- $\gamma$ overexpression triggers more inflammation and tissue damage and leads to SLE immunopathogenesis, as has been shown in other studies as INF- $\gamma$ mRNA regulation occurs in SLE patients' peripheral blood mononuclear cells Csiser et, al. ${ }^{10}$

The results are consistent with previous findings showing elevated serum IFN- $\gamma$ levels in SLE sufferers with nephritic syndrome or lymphadenopathy and endorse the hypothesis that IFN- $\gamma$ up regulates mononuclear cell IgG development in SLE patients. ${ }^{1,12}$

In the earlier onset of the disease following repetitive injections of recombinant IFN- $\gamma$ via the murine SLE model, the role of Th1 cytokine IFN- $\gamma$ in SLE production has been previously reported. ${ }^{13}$

A strong association among the intensity of SLE and the amount of IFN- $\gamma$ secreted by stimulated PBMC in SLE patients has also been shown in recent researches. $^{14}$

In $\mathrm{T}$ cell culture supernatants, overexpressed IFN- $\gamma$ also led to the excess sBLyS-inducing activity of SLE patients. ${ }^{4}$

Yu and Wang stated, in contrast to our research, that the IFN- $\gamma$ levels in the SLE group were lower than those in the control group. They clarified their outcome by stating that in various phases of the disease, cells of Th1 or Th2 can have various roles. In addition, the limited number of patients in their sample, which was only 20 , can be clarified. ${ }^{15}$

Furthermore there is a significant difference between lupus patient with nephritis and those without nephritis. Which reflect higher INF- $\gamma$ level produced in the patients with nephritis and this goes ahead with the previous knowledge that renal affection associated with increased INF- $\gamma$ gene signature. ${ }^{16,17,18,19}$

In his study of interferons and their association with the clinical manifestation, V Oke et al, also found that lupus nephritis was correlated with higher IFN- $\gamma$ plasma levels ${ }^{20}$.

There was a strong positive association among IFNgamma and SLEDAI serum levels, and substantial variations in IFN-gamma serum concentrations among mild and very high activity were substantially higher in patients with very high activity, meaning that the connection between the level of INF gamma and the degree of activity was substantially higher. This was in agreement with Gigante et el and others. ${ }^{10,21 \& 22}$
El-Sayed et al. and Harigai et al., on the other hand, found no association among IFN- $\gamma$ and SLEDAI. ${ }^{4 \& 23}$

And the level of expression of the IFN- $\gamma$ gene in the index study was substantially greater and was associated with SLEDAI and renal participation. A number of studies have previously established IFN's potential role in the pathogenesis of SLE. Hooks et al. This study showed a positive association between SLEDAI and INF gamma levels, supported by another study. ${ }^{24,25}$

The connection between SLE behavior and IFN- $\gamma$ was found to suggest that the function of IFN- $\gamma$ may be as significant as IFN type I in SLE. And thus, IFN- $\gamma$ may also become a significant objective for therapeutic strategies.

There had been a strong association among the INF$\gamma$ level and the level of $24 \mathrm{hr}$ protein in urine in patients with lupus nephritis, which is directly related to the degree of renal affection and consequently to the activity of the disease in those patients, An irregular proteinuria value in SLE has been recognized as a biological marker for kidney disease, with or without the involvement of substantial red blood cells, white blood cells or cellular casts of urine. ${ }^{26,28}$

And we found a significant association between the level of INF- $\gamma$ and certain clinical manifestations of SLE like arthritis, and this was previously shown by another cohort study which found a high level of INF gamma with active arthritis $\mathrm{V}$ Oke et al. and lymphopenia correlated with higher levels of INF gamma and that meets the outcome of other studies. ${ }^{20,28}$

In comparison to other studies that found a link between INF gamma and mucocutaneous manifestation, we found no connection between INF gamma and mucocutaneous manifestation. ${ }^{29}$

And there has been a strong connection among INF$\gamma$ level and the activity marker of LN anti ds- DNA titer and Kawamoto et al addressed this earlier in the Inducible Co-stimulator (ICOS) study, which is the third member of the CD28/cytotoxic T-lymphocyteassociated antigen-4 family and has been included in $\mathrm{T}$ cell proliferation and activation, and found that ICOS was over-expressed in patients with active SLE cells in CD4+ T peripheral blood cells and that ICOS led not just to elevated proliferation however also to elevated production of IFN- $\gamma$ in peripheral blood T cells in patients with SLE. ${ }^{30,31}$

We also notice significant correlation between complement consumption and level of INF- $\gamma$ and it is known that the low complement is one of the early parameters of LN activity, this was supported by other study in which there is significant correlation between c4 and INF- $\gamma$ level while there is no correlation with c3 level Elewa E et al. ${ }^{25}$ 


\section{CONCLUSION}

INF- $\gamma$ is one of the most fundamental contributors in the process of pathogenesis of SLE nowadays by different manners and pathways either direct or indirect.

There is direct connection between the level of INF gamma and the degree of activity and this confirmed by SLEDAI score correlation

The patients of lupus nephritis have the higher level of INF gamma and this connected to the elements of activity

There is selective manner of INF gamma level in relation to different system affection as we found it high in active arthritis and haematological disorder.

We recommend the wollowing, INF gamma should be used as abiomarker of activity of SLE and anti INF gamma should be studied as a line of treatment in the near future.

\section{REFERENCES}

1. Adhya Z, Borozdenkova S and Karim MY. The role of cytokines as biomarkers in Systemic Lupus Erythematosus and lupus nephritis. Nephrol Dial Transplant. 2011;26:3273-80.

2. Yap DY and Lai KN. Cytokines and their roles in the pathogeneis of Systemic Lupus Erythematosus: from basics to recent advances. $J$ Biomed Biotechnol. 2010:365083

3. Gottenberg JE and Chiocchia G. Dendritic cells and interferon mediated autoimmunity. Biochimie 2007;89:856-71.

4. Harigai $M$, Kawamoto $M$, Hara $M$, et al. Excessive production of IFN-gamma in patients with systemic lupus erythematosus and its contribution to induction of $\mathrm{B}$ lymphocyte stimulator/B cellactivating factor/TNF ligand superfamily-13B. J Immunol. 2008; 181: 2211-9.

5. Tokano Y, Morimoto S, Kaneko H, et al. Levels of IL-12 in the sera of patients with systemic lupus erythematosus (SLE)-relation to Th1- and Th2-derived cytokines. Clin Exp Immunol. 1999; 116: 169-73.

6. Chang DM, Su WL and Chu SJ. The expression and significance of intracellular $\mathrm{T}$ helper cytokines in systemic lupus erythematosus. Immunol Invest. 2002; 31: 1-12.

7. Gerez L, Shkolnik T, Hirschmann O, et al. Hyperinducible expression of the interferongamma (IFN- $\gamma)$ gene and its suppression in systemic lupus erythematosus (SLE). Clin Exp Immunol. 1997; 109: 296-303.

8. Jacob CO. In vivo treatment of (NZB X NZW)F1 lupus-like nephritis with monoclonal antibody to gamma interferon. J Exp Med. 1987; 166: 798803.

9. Ozmen L, Roman D, Fountoulakis M, et al. Experimental therapy of systemic lupus erythematosus: the treatment of NZB/W mice with mouse soluble interferon- $\gamma$ receptor inhibits the onset of glomerulonephritis. Eur J Immunol. 1995; 25: 6-12.

10. Csiszar A, Nagy G, Gergely P, et al. Increased interferon-gamma (IFN-C), IL-10 and decreased IL-4 mRNA expression in peripheral blood mononuclear cells (PBMC) from patients with Systemic Lupus Erythematosus (SLE). Clin Exp Immunol. 2000;122:464-70.

11. al-Janadi M, Al-Balla S, Al-Dalaan A, et al. Cytokine profile in systemic lupus erythematosus, rheumatoid arthritis and other rheumatic diseases. J Clin Immunol. 1993; 13:5867.

12. Takahashi S, Fossati L, Iwamoto R, et al. Imbalance towards Th1 predominance is associated with acceleration of lupus-like autoimmune syndrome in MRL mice. $J$ Clin Invest 1996; 97:1597-604.

13. Jacob CO, van der Meide PH and McDevitt HO. In vivo treatment of (NZBxNZW) F1 lupus-like nephritis with monoclonal antibody to $\mathrm{g}$ interferon. J Exp Med. 1987; 166:798-803.

14. Ferry B, Antrobus P, Huzicka I, et al. Intracellular cytokine expression in whole blood preparations from normals and patients with atopic dermatitis. Clin Exp Immunol.1997; 110:410-7.

15. Yu XM and Wang XF. The in vitro proliferation and cytokine production of $\mathrm{Va} 24+\mathrm{Vb} 11+$ natural killer $\mathrm{T}$ cells in patients with Systemic Lupus Erythematosus. Chin Med J (Engl). 2011;124:61-5.

16. A Rana , RW Minz , R Aggarwal , et al. Gene expression of cytokines (TNF-a, IFN-c), serum profiles of IL-17 and IL-23 in paediatric systemic lupus erythematosus. Lupus, 2012; 21, 1105-12.

17. Feng X, Wu H, Grossman JM, et al. Association of increased interferoninducible gene expression with disease activity and lupus nephritis in patients with systemic lupus erythematosus. Arthritis Rheum.2006; 54:2951-62.

18. Idborg H, Eketjäll S, Pettersson S, et al. TNF- $\alpha$ and plasma albumin as biomarkers of disease activity in systemic lupus erythematosus. Lupus Sci Med. 2018;5:000260.

19. Shiozawa, F.; Kasama, T.; Yajima, N.; Odai, T.; Isozaki, T.; Matsunawa, M.; Yoda, Y.; Negishi, M.; Ide, H.; Adachi, M. Enhanced expression of interferon-inducible protein 10 associated with Th1 profiles of chemokine receptor in autoimmune pulmonary inflammation of MRL/lprmice. Arthritis Res. Ther. 2003; 6;78.

20. Vilija Oke, Iva Gunnarsson1, Jessica Dorschner2 , Susanna Eketjäll3 , Agneta Zickert1 , Timothy B. Niewold2,4 and Elisabet Svenungsson. High levels of circulating interferons type I, type II and type III associate with distinct clinical features of active systemic lupus erythematosus . Arthritis Research \& Therapy . 2019; 21:107.

21. Gigante A, Gasperini ML, Afeltra A, et al. Cytokines expression in SLE nephritis. Eur Rev Med Pharmacol Sci. 2011;15:15-24.

22. Viallard JF, Pellegrin JL, Ranchin V, et al. Th1 (IL-2, interferon-gamma (IFN-C)) and Th2 (IL10, IL-4) cytokine production by peripheral blood mononuclear cells (PBMC) from patients with 
Systemic Lupus Erythematosus (SLE). Clin Exp Immunol. 1999;115:189-95.

23. El-Sayed M, Nofal E, Al-Mokadem S, et al. Correlative study of serum Th1/Th2 cytokines levels in patients with Systemic Lupus Erythematosus with SLEDAI. Egypt Dermatol Online J. 2008; 4.

24. Hooks JJ, Moutsopoulos HM, Geis SA, et al. Immune interferon in the circulation of patients with autoimmune disease. $N$ Engl $J$ Med. 1979; 301: 5-8.

25. Elewa EA, Zakaria O, Mohamed EI, et al. The role of interleukins 4, 17 and interferon gamma as biomarkers in patients with Systemic Lupus Erythematosus and their correlation with disease activity. The Egyptian Rheumatologist. 2014; 36:21-7.

26. Petri M, Barr SG, Zonana-Nach A et al.: Measures of disease activity, damage, and health status: The Hopkins Lupus Cohort experience. $J$ Rheumatol 1999; 26: 502-3.

27. . Chakrabarti S, Ghosh AK, Bose J, et al.: Clinicopathological study of lupus nephritis. $J$ Indian Med Assoc, 1998; 96: 268-71.

28. Bennett L., Palucka AK, Arce E.,V. Cantrell, J. Borvak, J. Banchereau, and V. Pascual. 2003. Interferon and granulopoiesis signatures in systemic lupus erythematosus blood. J. Exp. Med. 2003; 197: 711-23.

29. Hutloff A, Buchner K, Reiter $K$, et al. Involvement of inducible costimulator in the exaggerated memory B cell and plasma cell generation in systemic lupus erythematosus. Arthritis Rheum 2004, 50:3211-20.

30. Lawson BR, Prud'homme GJ, Chang Y, et al. Treatment of murine lupus with cDNA encoding IFN-gammaR/Fc. J Clin Invest. 2000, 106:20715. 